\title{
VARIATION IN HIP AND SEPAL PARAMETERS OF INVASIVE ROSA RUGOSA BETWEEN SITES AND YEARS
}

\author{
Zigmantas GudžInSKas $^{1 *}$, Mindaugas RASIMAVIČIUS ${ }^{2}$ \\ ${ }^{1}$ Nature Research Centre, Institute of Botany, Žaliujjų Ežerų Str. 49, 12200 Vilnius, Lithuania \\ ${ }^{2}$ Life Sciences Center, Vilnius University, Institute of Biosciences, Saulètekio Av. 7, 10257 Vilnius, Lithuania \\ *Corresponding author. E-mail: zigmantas.gudzinskas@gamtc.lt
}

\begin{abstract}
Gudžinskas Z., Rasimavičius M., 2021: Variation in hip and sepal parameters of invasive Rosa rugosa between sites and years. - Botanica, 27(1): 1-12.

Rosa rugosa is among the most invasive species in Europe, and it is considered a severe threat to the diversity and stability of coastal habitats. In Lithuania, it is a widespread invasive species occurring in coastal and inland areas. This research aimed to estimate the variation in $R$. rugosa hip and sepal parameters within and among sites from coastal and inland areas, and investigate the effects of environmental factors on the hip and sepal sizes. Field studies were performed at four coastal and three inland sites in 2008, and the studies were repeated in 2016. We collected 100 mature hips at each site and measured the hip width, hip length and sepal length. We analysed variation in hip and sepal parameters between the study years, and the effect of meteorological factors and agrochemical properties of the soil on hip and sepal sizes. This study revealed significant variation in $R$. rugosa hip width, hip length and sepal length among the studied sites. The largest hips and sepals were found in the coastal habitat at the Smelte site, whereas the smallest hips and sepals were recorded in inland habitat at the Staviškès site, where R. rugosa occurred in woodland. The comparison of hip and sepal sizes at the same sites during two study years revealed irregular variation. Mean hip width and mean length of sepals in 2008 were significantly more prominent than in 2016, whereas no significant differences in hip length were found between the study years. The content of phosphorus in the soil negatively correlated, whereas the content of carbonates positively correlated with the sepal length. A strong negative relationship was found between the sunshine duration and hip length and width ratio. However, the revealed relationships of the hip and sepal parameters with the environmental factors could be a coincidence or a result of the cumulative effect of the multiple factors' interaction and should be investigated separately.
\end{abstract}

Keywords: coastal habitats, fruits, inland habitats, meteorological factors, reproductive traits, shrub, soil properties.

\section{INTRODUCTION}

Rosa rugosa Thunb. (Rosaceae) is a rhizomatous shrub, forming dense thickets. It is recognised as an invasive alien species in several countries of Europe (WEIDEMA, 2006; GUDŽINSKAS \& ŽALNERAVIČIUS, 2017; Nentwig et al., 2018). The invasion of $R$. rugosa and its effect on native species and communities have been extensively studied in the coastal areas of Europe and North America, particularly along the coasts of the Northern Atlantic, the North Sea and the
Baltic Sea (BRuUn, 2005; Isermann, 2008; JøRGENSEN \& Kollmann, 2009; Hill et al., 2010; Garbary et al., 2013; Kunttu \& Kunttu, 2017). A strong negative impact of $R$. rugosa has been found on the diversity of native species (IsERMANN, 2003, 2008; WeIDEMA, 2006) and the structure of coastal plant communities (Bruun, 2005; Weidema, 2006). Besides, the increasing frequency of spontaneous hybridisation of R. rugosa with native congeners in Europe has been noted (Weidema, 2006; Kellner et al., 2012); therefore, this process may negatively affect the genetic 
stability of native Rosa species. Although the ecological effect of invasive $R$. rugosa is mainly negative, from the socio-economic perspective, it is frequently considered a useful plant primarily because of its ornamental and medicinal properties (НАSHIDOKO, 1996; Cunja et al., 2016; Dudra et al., 2016; MÁrMOL et al., 2017; OLECH et al., 2017).

Rosa rugosa is native to the Northern Pacific region in Eastern Asia (Bruun, 2005). In the native range, it usually grows below $100 \mathrm{~m}$ a. s. 1. in sandy soil and mainly occupies dune, hillside, rocky shore and meadow habitats (CUIZHI \& RoBERTSON, 2003; BRUun, 2005). In Europe, this species was introduced as early as 1796 (BRUUN, 2005). Since the 19th century it has been widely cultivated in gardens, ornamental plantations, and for coastal sand stabilisation (NORDSTROM et al., 2000; BRUUn, 2005; IsERMANN, 2008).

In Lithuania, $R$. rugosa is a widely distributed alien species occurring in coastal areas of the Baltic Sea as well as in inland areas (GuDŽInSKAS, 2000; GuDŽINSKAS \& ŽALNERAVIČIUS, 2017). Since the 1970s, extensive experiments on the cultivation of $R$. rugo$s a$ in seminatural ecosystems have been performed in Lithuania. It has been recommended for cultivation as an ornamental and fruit plant, for stabilisation of steep hill slopes, continental sands and coastal dunes (Apalia et al., 1978). Large scale introduction of $R$. rugosa has resulted in its wide naturalisation and further spread, particularly since the 1990 s, in seminatural and natural ecosystems. Currently, it is included into the List of Invasive Species of Lithuania (GUDŽINSKAS \& ŽALNERAVIČIUS, 2017).

Studying $R$. rugosa distribution and habitats invaded in Lithuania, we noted substantial variation in the size and shape of hips and sepals in coastal and inland habitats. Therefore, we had a question what factors determine the size of hips and sepals? The hip size is an essential reproductive trait, because larger hips usually contain more seeds, which play a vital role in the spread of $R$. rugosa over significant distances and invading new areas (BRUUN, 2005; Kollmann et al., 2009; Tong et al., 2017; ZHANG et al., 2018). Although persistent sepals do not play an essential role in reproduction, they are an integral part of the hip. The size of sepals is a functional trait because they perform photosynthesis and, at a certain level, contribute to the accumulation of organic material in the plant.
This research aimed to answer the following questions: (a) what is the variation in R. rugosa hip and sepal parameters at different sites?; (b) how do the analysed traits differ between years in the same population?; (c) what is the effect of the coastal and inland habitat?; (d) how do soil agrochemical characteristics and meteorological factors affect hip and sepal parameters?

\section{MATERIALS AND METHODS}

\section{Study sites}

Thickets of R. rugosa, occupying at least $100 \mathrm{~m}^{2}$ in homogeneous habitat, were selected for this study. We performed a sampling of $R$. rugosa hips in two stages, in August and September of 2008 and 2016. Coastal thickets of $R$. rugosa were selected in the Curonian Spit (Neringa city), Nemirseta (Palanga city) and Smelte (Klaipeda city). In the continental part of the country, for the study, we selected sites in Darželiai village (Varėna district), Staviškès (Vilnius city) and Pikeliai village (Raseiniai district). In total, this species was sampled at seven sites (Fig. 1, Table 1).

The habitat types of the study sites were identified and named after the EUNIS Habitat Classification (European Environmental Agency, 2017). Hips of R. rugosa were collected from the northern fixed grey dune (B1.41), Baltic sand beach perennial community (B1.232), unmanaged xeric grassland (E1.D), unmanaged mesic grassland (E2.7) and mixed Scots pinebirch woodland (G4.4) habitats (Table 1). The coverage of $R$. rugosa shrubs at the sampling sites ranged from $30 \%$ to $70 \%$. All sites, except for mixed Scots pinebirch woodlands, were open, well-illuminated, without or with insignificant (less than 5\%) coverage of native shrubs. Coverage of the tree layer, dominated by Pinus sylvestris and Betula pendula, in the sampled mixed Scots pine-birch woodland habitat was ca. 50\%.

\section{Sampling procedures}

Individual reproductive shoots for sampling were selected with at least $1 \mathrm{~m}$ distance from the stand's edge and at least $2 \mathrm{~m}$ between sampled shoots. Two hips, the central and one lateral, were collected from the upper branch of 50 shoots. At each study site, 100 ripe hips (turned orange or red) of $R$. rugosa without evident mechanical injuries, deformations and symp- 


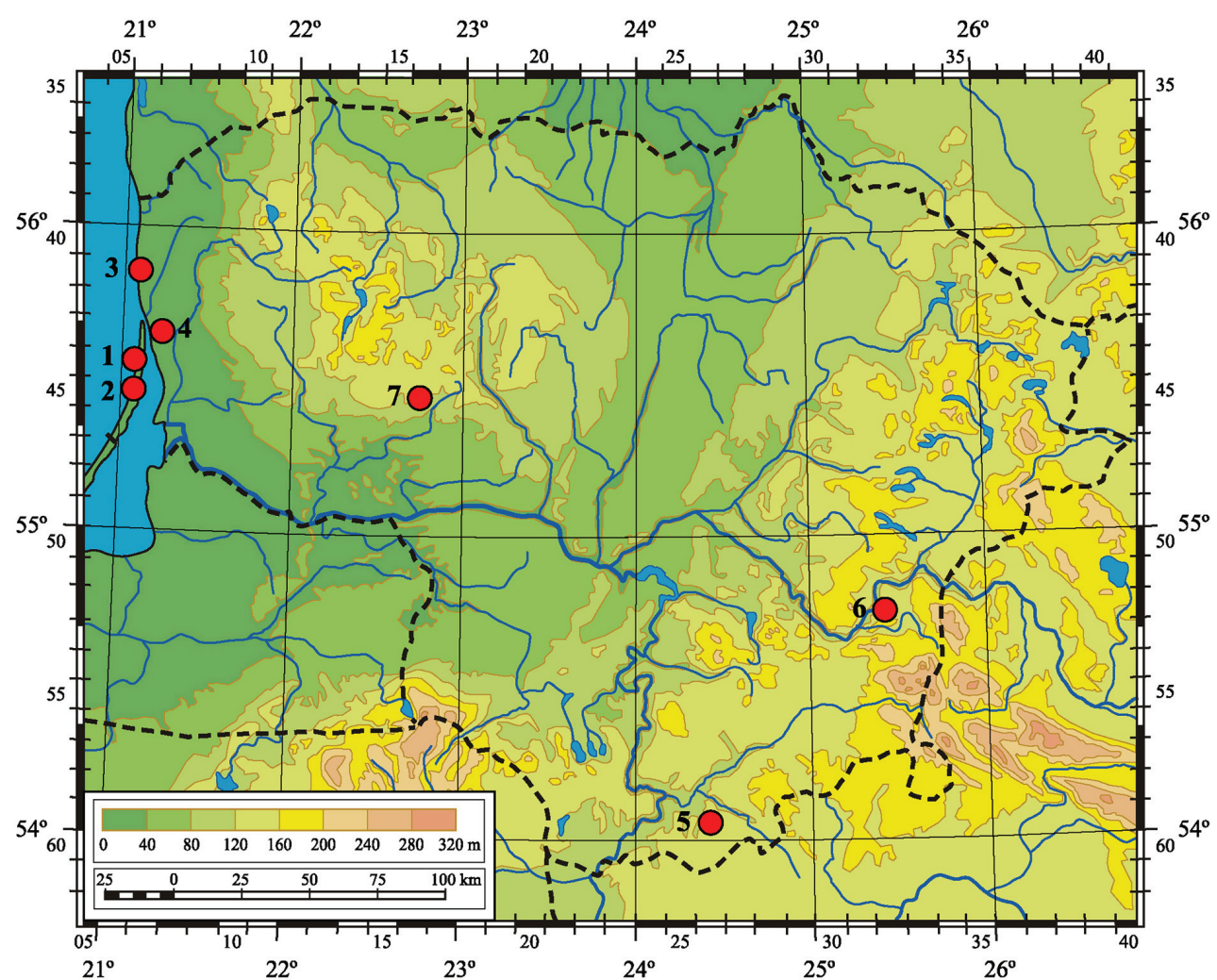

Fig. 1. Map of Rosa rugosa hip sampling sites in 2008 and 2016. Site numbers correspond to the numbers in Table 1

Table 1. Location of Rosa rugosa hip sampling sites and occupied types of habitats according to the EUNIS habitat classification

\begin{tabular}{|c|l|l|c|c|c|c|}
\hline Site No. & Site name & Administrative unit & Latitude $\left({ }^{\circ} \mathrm{N}\right)$ & Longitude $\left({ }^{\circ} \mathrm{E}\right)$ & Elevation $(\mathrm{m}$ a.s.1.) & Habitat type \\
\hline 1 & Juodkrantė & Neringa & 55.950257 & 21.943774 & 6 & B1.41 \\
\hline 2 & Avikalnis & Neringa & 55.516227 & 21.116153 & 1 & B1.41 \\
\hline 3 & Nemirseta & Palanga & 55.866539 & 21.058786 & 7 & B1.232 \\
\hline 4 & Smelte & Klaipėda & 55.638430 & 21.152712 & 2 & B1.232 \\
\hline 5 & Darželiai & Varèna & 54.012920 & 24.340600 & 116 & E1.D \\
\hline 6 & Staviškès & Vilnius & 54.755192 & 25.336300 & 116 & G4.4 \\
\hline 7 & Pikeliai & Raseiniai & 55.463909 & 22.685917 & 144 & E2.7 \\
\hline
\end{tabular}

toms of diseases were collected. Picked up hips were placed into the labelled plastic bag and brought to the laboratory for further analysis.

The collected hips of $R$. rugosa were analysed at the laboratory the same or the following day. Hip width, length and length of the longest sepal were measured using an electronic calliper (WZ SL 150D) with the precision of $0.1 \mathrm{~mm}$. The length of the hip was measured from the pedicel to the base of the hip neck. The width of the hip was measured approximately at its middle (Fig. 2). The ratio between the hip length and width was calculated, dividing the length by the width.

\section{Environmental conditions}

The data on meteorological conditions of the study sites were extracted from the published Yearbooks of the Lithuanian Hydrometeorological Service (Kitriené, 2009; Kazlauskiené \& Kitriené, 2017). Information obtained from the closest to the study site Meteorological Station was considered. The mean temperature of January and July, the sum of precipitation of the year and duration of annual sunshine (in hours) were analysed.

Mixed soil samples of ca. $1 \mathrm{~kg}$, composed of four subsamples (ca. $0.25 \mathrm{~kg}$ ) taken across the studied stand of $R$. rugosa, were prepared for agrochemical 


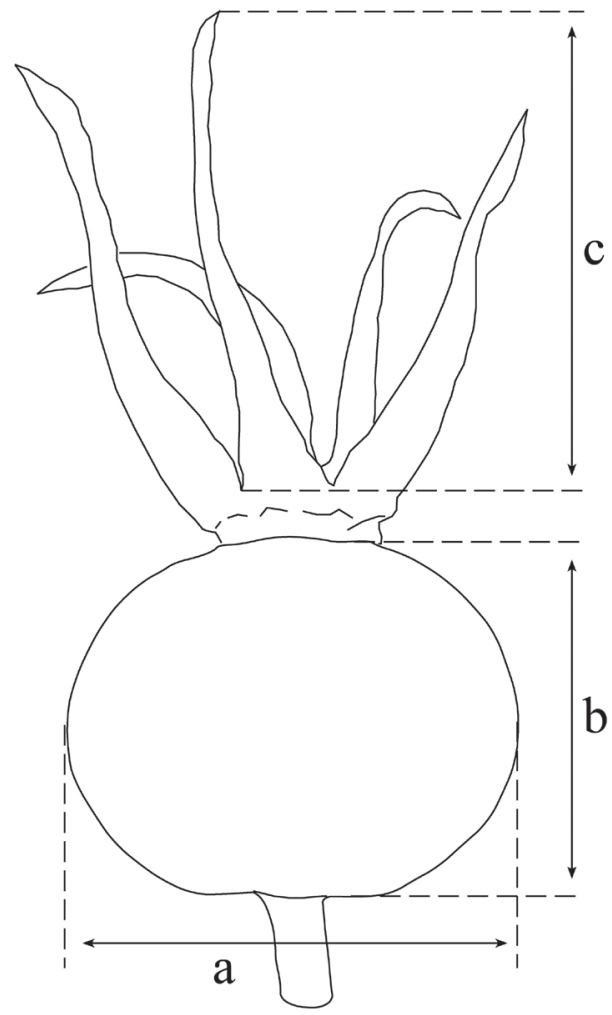

Fig. 2. Scheme of the measurement of the hip width (a), length (b) and the sepal length (c)

analyses. The soil was dug from $0-30 \mathrm{~cm}$ depth after removing the living plants and the layer of plant debris. Agrochemical analyses of soil samples were performed at the Laboratory of Agrochemical Analyses of the Lithuanian Research Centre for Agriculture and Forestry (Kaunas, Lithuania) according to certified procedures and protocols (VolungEVIČIUs et al., 2015). The following agrochemical parameters were analysed: quantity of humus (\%), $\mathrm{pH}$ (in water solution, $\mathrm{mol} / \mathrm{l}$, in $\mathrm{KCl}$ suspension), the content of phosphorus $\left(\mathrm{P}_{2} \mathrm{O}_{5}\right)$, potassium $\left(\mathrm{K}_{2} \mathrm{O}\right)$, total nitrogen and total carbonates $\left(\mathrm{CaCO}_{3}\right)(\mathrm{mg} / \mathrm{kg})$.

\section{Statistical analyses}

The results of descriptive statistical analysis were reported as means and standard deviations (mean \pm SD). The normality of data distribution was evaluated using Shapiro-Wilk's test. The data on the hip morphological parameters (width and length of hips, length of sepals) were normally distributed; therefore, parametric tests were applied. One-way ANOVA tests were used to compare differences between hip length, hip width, hip length and width ratio and the length of sepals, and $F$ value was presented, indicating in parenthesis the number of degrees of freedom $(d f)$ between groups and within groups. Student's $t$ test was applied to determine the difference between hip and sepal parameter between years two data sets. As most of the data sets on meteorological conditions and soil properties were non-normally distributed, Spearman's rank-order correlation $\left(\mathrm{r}_{\mathrm{s}}\right)$ was used to test for dependencies between the environmental data and means of morphological parameters; however, Pearson's linear correlation (r) was used to test dependencies between normally distributed datasets of morphological characters. Differences and correlations were considered significant at $p<0.05$. All calculations were performed using PAST 3.20 (HAMMER et al. 2001).

\section{RESULTS}

\section{Hip and sepal traits}

The analysis of hip measurements revealed that mean hip width at individual study sites ranged from $16.11 \pm 2.59 \mathrm{~mm}$ (Staviškès) to $29.48 \pm 2.57 \mathrm{~mm}$ (Smelte) in 2008 and from $15.89 \pm 2.42 \mathrm{~mm}$ (Staviškès) to $28.67 \pm 4.03$ (Smelte) in 2016 (Table 2). The width of individual hips at the study sites ranged from $12.0 \mathrm{~mm}$ to $39.0 \mathrm{~mm}$ in 2008 and from $11.1 \mathrm{~mm}$ to $45.3 \mathrm{~mm}$ in 2016. ANOVA tests revealed significant differences between the means of hip width among study sites in $2008(F(6,693)=303.2$, $p<0.001)$ and $2016(F(6,693)=213.1, p<0.001)$.

The mean length of hips at the study sites ranged from $12.37 \pm 2.05 \mathrm{~mm}$ (Staviškès) to $19.49 \pm 2.31 \mathrm{~mm}$ (Pikeliai) in 2008 and from $12.36 \pm 1.68$ (Staviškès) to $21.33 \pm 2.97$ (Pikeliai) in 2016 (Table 2). The length of individual hips at the study sites ranged from $9.1 \mathrm{~mm}$ to $29.0 \mathrm{~mm}$ in 2008 and from $8.7 \mathrm{~mm}$ to $45.5 \mathrm{~mm}$ in 2016. ANOVA tests revealed significant differences between the means of hip length among study sites in $2008(F(6,693)=157.9, p<0.001)$ and $2016(F(6,693)=154.8, p<0.001)$.

The ratio between hip length and width, which describes a dominant form of hips, at the study sites ranged from $0.64 \pm 0.05$ (Smelte) to $0.87 \pm 0.08$ (Darželiai) in 2008 and from $0.73 \pm 0.07$ (Juodkrante) to $0.82 \pm 0.08$ (Darželiai) in 2016 (Table 2). The ratio of individual hip length and width ranged from 
Table 2. Descriptive statistics of Rosa rugosa hip and sepal characters at the study sites in 2008 and 2016 (mean \pm SD)

\begin{tabular}{|c|c|c|c|c|c|}
\hline Sites & Year of sampling & Hip width (mm) & Hip length (mm) & $\begin{array}{c}\text { Hip length and } \\
\text { width ratio }\end{array}$ & Sepal length (mm) \\
\hline \multirow{2}{*}{ Juodkrantè } & 2008 & $24.21 \pm 2.46$ & $16.94 \pm 1.79$ & $0.70 \pm 0.06$ & $29.22 \pm 4.95$ \\
\hline & 2016 & $24.75 \pm 2.62$ & $17.96 \pm 1.76$ & $0.73 \pm 0.07$ & $23.37 \pm 3.55$ \\
\hline \multirow{2}{*}{ Avikalnis } & 2008 & $25.07 \pm 3.11$ & $18.03 \pm 2.44$ & $0.72 \pm 0.08$ & $30.87 \pm 5.57$ \\
\hline & 2016 & $23.83 \pm 3.28$ & $17.94 \pm 3.50$ & $0.75 \pm 0.10$ & $25.75 \pm 5.23$ \\
\hline \multirow{2}{*}{ Nemirseta } & 2008 & $27.07 \pm 2.77$ & $18.77 \pm 1.67$ & $0.70 \pm 0.04$ & $27.19 \pm 4.41$ \\
\hline & 2016 & $22.22 \pm 2.74$ & $17.07 \pm 1.71$ & $0.77 \pm 0.08$ & $20.47 \pm 3.70$ \\
\hline \multirow{2}{*}{ Smeltè } & 2008 & $29.48 \pm 2.57$ & $18.83 \pm 1.68$ & $0.64 \pm 0.05$ & $35.51 \pm 6.26$ \\
\hline & 2016 & $28.67 \pm 4.03$ & $20.82 \pm 2.35$ & $0.73 \pm 0.09$ & $29.21 \pm 6.74$ \\
\hline \multirow{2}{*}{$\begin{array}{l}\text { All coastal } \\
\text { pooled }\end{array}$} & 2008 & $26.46 \pm 3.40$ & $18.14 \pm 2.06$ & $0.69 \pm 0.07$ & $30.70 \pm 6.15$ \\
\hline & 2016 & $24.87 \pm 3.99$ & $18.45 \pm 2.81$ & $0.75 \pm 0.09$ & $24.70 \pm 5.91$ \\
\hline \multirow{2}{*}{ Darželiai } & 2008 & $22.19 \pm 2.11$ & $19.27 \pm 1.78$ & $0.87 \pm 0.08$ & $31.20 \pm 5.14$ \\
\hline & 2016 & $21.41 \pm 2.26$ & $17.45 \pm 1.92$ & $0.82 \pm 0.08$ & $30.27 \pm 5.01$ \\
\hline \multirow{2}{*}{ Staviškès } & 2008 & $16.11 \pm 2.59$ & $12.37 \pm 2.05$ & $0.77 \pm 0.08$ & $20.99 \pm 2.96$ \\
\hline & 2016 & $15.89 \pm 2.42$ & $12.36 \pm 1.68$ & $0.78 \pm 0.07$ & $19.49 \pm 4.22$ \\
\hline \multirow{2}{*}{ Pikeliai } & 2008 & $28.80 \pm 3.69$ & $19.49 \pm 2.31$ & $0.68 \pm 0.06$ & $29.42 \pm 4.57$ \\
\hline & 2016 & $28.54 \pm 3.47$ & $21.33 \pm 2.97$ & $0.75 \pm 0.10$ & $35.09 \pm 5.75$ \\
\hline \multirow{2}{*}{$\begin{array}{l}\text { All inland } \\
\text { pooled }\end{array}$} & 2008 & $22.37 \pm 5.75$ & $17.04 \pm 3.90$ & $0.77 \pm 0.11$ & $27.20 \pm 6.17$ \\
\hline & 2016 & $21.95 \pm 5.87$ & $17.05 \pm 4.31$ & $0.78 \pm 0.09$ & $28.28 \pm 8.24$ \\
\hline \multirow{2}{*}{$\begin{array}{l}\text { All sites } \\
\text { pooled }\end{array}$} & 2008 & $24.70 \pm 4.98$ & $17.67 \pm 3.03$ & $0.73 \pm 0.10$ & $29.20 \pm 6.39$ \\
\hline & 2016 & $23.62 \pm 5.09$ & $17.84 \pm 3.60$ & $0.76 \pm 0.09$ & $26.24 \pm 7.22$ \\
\hline
\end{tabular}

0.50 to 1.11 in 2008 and from 0.40 to 1.34 in 2016 . Thus, the form of hips can be defined as ranging from strongly depressed to ovoid. ANOVA tests revealed significant differences between the ratio of hip length and width among populations in $2008(F(6,693)=$ $130.9, p<0.001)$ and $2016(F(6,693)=13.4$, $p<0.001)$.

The mean length of sepals at individual study sites ranged from $20.99 \pm 2.96 \mathrm{~mm}$ (Staviškès) to $35.51 \pm 6.26 \mathrm{~mm}$ (Smelte) in 2008 and from 19.49 $\pm 4.22 \mathrm{~mm}$ (Staviškès) to $35.09 \pm 5.75 \mathrm{~mm}$ (Pikeliai) in 2016 (Table 2). The length of sepals on individual hips ranged from $14.1 \mathrm{~mm}$ to $53.0 \mathrm{~mm}$ long in 2008 and from $11.5 \mathrm{~mm}$ to $51.0 \mathrm{~mm}$ in 2016 . ANOVA tests revealed significant differences between the length of sepals among the study sites in $2008(F(6$, $693)=81.4, p<0.001)$ and in $2016(F(6,693)=$ 127.2, $p<0.001)$.

\section{Variation in different years}

Comparing hip features and sepal length at the same sites in two study years applying Student's $t$ test revealed an irregular pattern of variation. Differences in the hip width were nonsignificant at four study sites in 2008 and 2016. At three study sites, hips were significantly wider in 2008 than in 2016. The most significant differences in the hip width between years were registered in Nemirseta (Table 2, Fig. 3). The hip length was significantly different in 2008 and 2016 at all sites, except for Avikalnis and Staviškès (Fig. 3). Although the hip width in 2008 was the same or more prominent than in 2016, the hip lengths at Juodkrante, Smelte and Pikeliai sites were larger, whereas, at Nemirseta and Darželiai, it was smaller in 2016 than in 2008 (Table 2, Fig. 3).

The ratio of hip length and width in 2008 and 2016 was significantly different at all study sites, except Staviškès. The analysis revealed that the ratio of hip length and width was larger in 2016 than in 2008 at all coastal sites, whereas at inland sites, the ratio varied irregularly (Table 2, Fig. 3). Thus, in 2016, the hips of $R$. rugosa occurring in coastal habitats were less compressed than in 2008.

The sepals' length was also significantly different between years at all sites, except for Darželiai (Table 2, Fig. 3). The analysis revealed that sepals in 2008 were more extended than in 2016 at all sites, except for Pikeliai. It should be noted that at the Staviškès site, the length of sepals was significantly different in 2008 and 2016. In contrast, no significant differences 

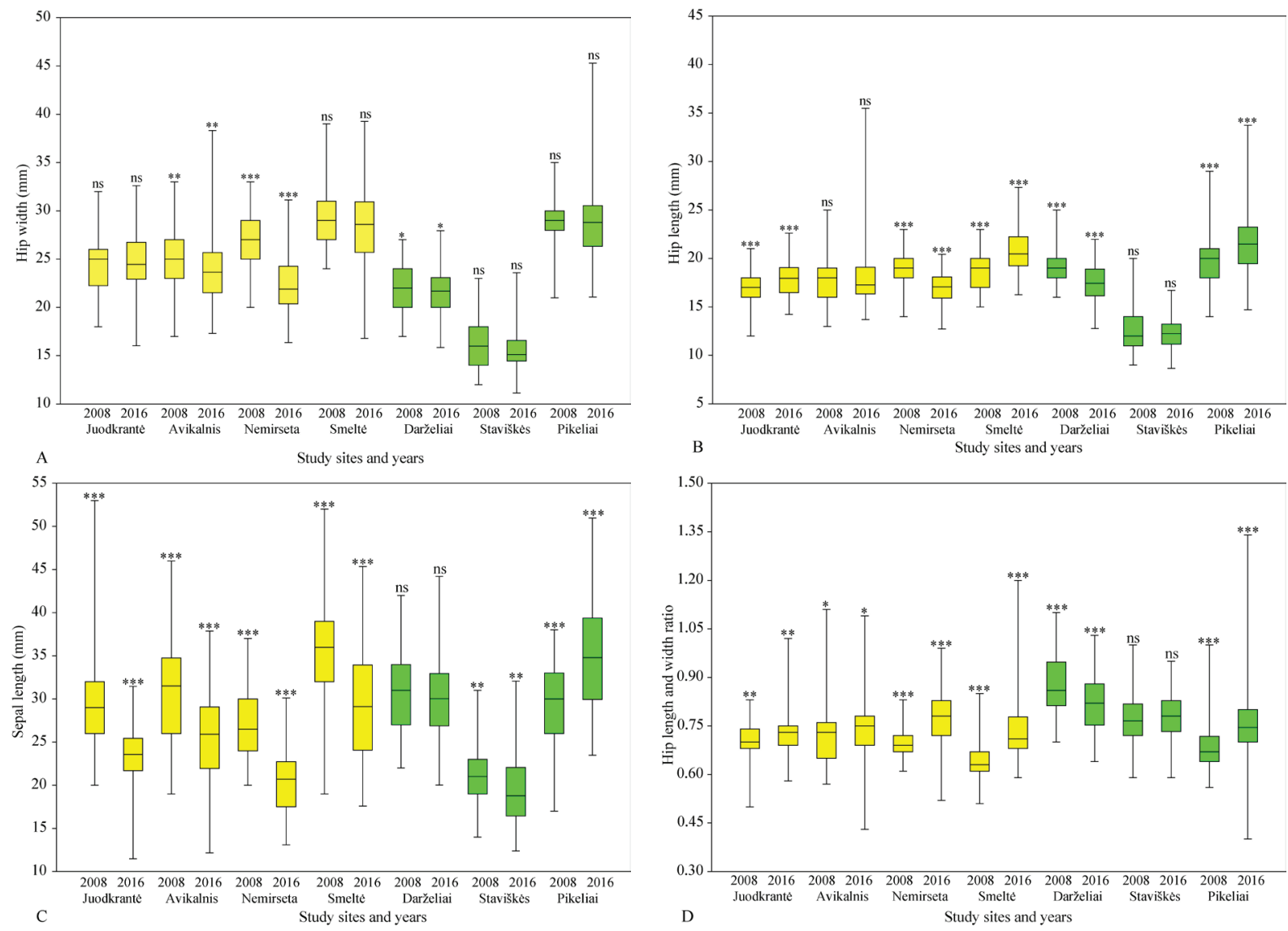

Fig. 3. Box plots with a comparison of hip length (A), hip width (B), sepal length (C) and the ratio between hip length and width (D) in Rosa rugosa populations in 2008 and 2016. The box represents the second and third quartiles (25-75\%), horizontal line inside the box represents the median, and whiskers represent the minimum and maximum values. Yellow box plots represent coastal and green box plots represent inland habitats. Significance of differences between the study years at the same site according to Student's $t$-test results is indicated above the whiskers: ${ }^{*}-p<0.05 ; *^{*}-p<0.01 ; * * *-p<0.001$; ns - nonsignificant

of all analysed hip parameters were found at this site between the study years.

Data analysis on the hip parameters and sepal length of pooled coastal, inland and all sites between the study years revealed interesting regularities. According to Student's $t$-test results, the hip width at all sites pooled was significantly larger $(t=4.04$, $p<0.001)$ in 2008 than in 2016. At coastal sites, hips were also significantly wider $(t=6.06, p<0.001)$ in 2008 than in 2016, whereas at inland sites differences were nonsignificant $(t=0.88, p=0.377$ ) between years. In contrast, hips in 2008 were shorter than in 2016 (Table 2), however, differences were nonsignificant at all sites pooled $(t=0.98, p=0.325)$, at coastal $(t=1.75, p=0.081)$ and inland $(t=0.01$, $p=0.992)$ sites. The same trend was found analysing the hip length and width ratio. The ratio was significantly larger in 2016 than in 2008 at all sites pooled $(t=7.46, p<0.001)$, however, at inland sites the difference between years was nonsignificant $(t=1.28$, $p=0.202)$, whereas at coastal sites the difference was significant $(t=10.48, p<0.001)$. Thus, hips in 2016 were generally less compressed than in 2008, particularly at coastal sites. A somewhat different pattern of sepal length variation between the study years was found. Although sepals at all sites pooled were significantly longer in 2008 than in $2016(t=8.13$, $p<0.001)$, at inland sites differences were nonsignificant $(t=1.82, p=0.069)$ and slightly shorter in 2008 than in 2016. In contrast, at coastal sites, sepals were significantly longer $(t=14.07, p<0.001)$ in 2008 than in 2016. Thus, differences in all analysed 
parameters at inland sites between years were nonsignificant, whereas these parameters at coastal habitats were significantly different.

\section{Effect of environmental conditions}

The mean annual temperature at the study sites in 2008 and 2016 varied insignificantly. At the coastal sites, it ranged from $8.7^{\circ} \mathrm{C}$ to $9.4^{\circ} \mathrm{C}$ in 2008 and from $8.2^{\circ} \mathrm{C}$ to $9.1^{\circ} \mathrm{C}$ in 2016 . At the inland sites, the mean annual temperature went from $7.8^{\circ} \mathrm{C}$ to $8.1^{\circ} \mathrm{C}$ in 2008 and from $7.3^{\circ} \mathrm{C}$ to $7.4^{\circ} \mathrm{C}$ in 2016 . The mean temperature of January in 2008 ranged from $-1.6^{\circ} \mathrm{C}$ to $1.1^{\circ} \mathrm{C}$, whereas in 2016 , it ranged from $-7.7^{\circ} \mathrm{C}$ to $-3.9^{\circ} \mathrm{C}$. The mean temperature of June in 2008 (varied from $15.1^{\circ} \mathrm{C}$ to $16.8^{\circ} \mathrm{C}$ ) was lower than in 2016 (from $15.9^{\circ} \mathrm{C}$ to $17.4^{\circ} \mathrm{C}$ ). The sum of annual precipitation in 2008 ranged from $688.1 \mathrm{~mm}$ to $886.5 \mathrm{~mm}$, and it was higher than in 2016, when it ranged from $686.4 \mathrm{~mm}$ to $848.3 \mathrm{~mm}$. The annual duration of the sunshine comprised 2060-2067 h at the coastal sites, and $1612-1770 \mathrm{~h}$ at the inland sites in 2008, whereas in 2016, it comprised 1911-2001 h at the coastal, and $1581-1603 \mathrm{~h}$ at the inland habitats. However, a few statistically significant relationships were found between the values of hip and sepal parameters and meteorological factors. A strong negative correlation was found between the annual duration of the sunshine and the hip length and width ratio $\left(\mathrm{r}_{\mathrm{s}}=-0.71\right.$, $p=0.004)$. Significant moderate negative correlations were also found between the hip length and width ratio and the mean annual temperature $\left(\mathrm{r}_{\mathrm{s}}=-0.55, p=\right.$ $0.040)$ as well as the sum of annual precipitation $\left(\mathrm{r}_{\mathrm{s}}=\right.$ $-0.54, p=0.048)$. The hip width also negatively correlated with the mean June temperature $\left(\mathrm{r}_{\mathrm{s}}=-0.53\right.$, $p=0.049$ ).

The content of total nitrogen in the soil at $R$. rugosa sites, in general, was low and ranged from $0 \%$ to $0.48 \%$. The content of phosphorus and potassium varied significantly between the study sites (their content ranged from $23 \mathrm{mg} / \mathrm{kg}$ to $697 \mathrm{mg} / \mathrm{kg}$ and from $14 \mathrm{mg} / \mathrm{kg}$ to $187 \mathrm{mg} / \mathrm{kg}$, respectively). Humus content in the soil of the study sites was in general low, and only at Pikeliai sites, the soil contained a moderate amount of humus (3.66\%). Soil pH in the habitats of the studied sites was close to neutral or slightly alkaline (pH 6.3-7.6). Differences between the agrochemical properties of the soil samples from the same sites in 2008 and 2016 were nonsignificant.
The analysis revealed a few significant correlations between the agrochemical properties of the soil and hip and sepal parameters. A moderate negative correlation was found between the content of phosphorus in the soil and sepal length $\left(\mathrm{r}_{\mathrm{s}}=-0.58, p=0.029\right)$, and a moderate positive correlation was found between the content of carbonates in the soil and sepal length $\left(\mathrm{r}_{\mathrm{s}}=0.67, p=0.009\right)$.

\section{DISCUSSION}

\section{Hip and sepal sizes}

Quite a few studies on the variation in R. rugosa hip and sepal parameters have been performed in the native and invasive ranges of the species. Mature hips of $R$. rugosa are usually characterised as depressed-globose, 15-20 mm (BRUUn, 2005) or 18$20 \mathrm{~mm}$ (Lewis et al., 2014) long and 20-25 mm wide (Cuizhi \& Robertson, 2003; Bruun, 2005; Lewis et al., 2014). The results of this study revealed specific differences in hip sizes, particularly at a site level. Although mean values of the hip width of the pooled sites are comparable with the hip width reported by other authors (Cuizhi \& Robertson, 2003; Bruun, 2005; Lewis et al., 2014), at two studied sites, mean width significantly exceeded the reported values (Table 2). In the populations from China, the mean hip width range from $20.40 \pm 5.00 \mathrm{~mm}$ to $24.40 \pm$ $3.30 \mathrm{~mm}$ (Tong et al., 2017). Thus, the mean values of the hip width at two sites (Smelte and Pikeliai) from Lithuania exceeded the values of those from China.

Mean hip length at the sites from Lithuania (Table 2) slightly exceeded mean length values reported by other authors (CUIZHI \& RoBerTson, 2003; BRUUN, 2005; Lewis et al., 2014). The reported hip length values from China range from $16.90 \pm 3.00 \mathrm{~mm}$ to $20.30 \pm 3.60 \mathrm{~mm}$ (Tong et al., 2017). Thus, the mean hip length in the studied populations of $R$. rugosa in China and Lithuania (Table 2) are similar.

We suppose that at least some populations of $R$. rugosa with significantly wider hips may represent descendants of purposefully selected accessions or cultivars with large hips (BUTKIENĖ, 1971; MONDER, 2012). According to ButKIENE (1971), at least 50 accessions of $R$. rugosa obtained from collections, nurseries and other sources have been cultivated for experiments and used for further propagation in 
Lithuania since the mid-1960s. Furthermore, studies on the genetic diversity of R. rugosa in the native and invasive ranges have revealed its multiple introductions from East Asia and a large genetic diversity of invasive populations (KeLAGER et al., 2013) and support our presumption.

ZHANG et al. (2018) have reported that the mean hip length and width ratio in two studied native populations from China is $0.94 \pm 0.11$ (range $0.80-1.18$ ), whereas the mean ratio in five populations in its invasive range from Germany, Denmark and Sweden is significantly lower, $0.72 \pm 0.09$ (range $0.59-1.02$ ). Our results are comparable with the native and invasive populations; however, the hip length and width ratio of individual hips from Lithuania varied in a broader range $(0.40-1.34)$. It should be noted that the hip length and width ratio in Darželiai $(0.87 \pm 0.08)$ was close to the value reported for two populations from China (ZhANG et al., 2018). This fact enables us to suppose that $R$. rugosa in Darželiai maybe represents wild accession of the species, which has not undergone breeding.

Quite contrasting results of $R$. rugosa hip sizes have been obtained by CunJA et al. (2016). They have analysed 30 hips of $R$. rugosa cultivated in Volčji Potok Arboretum (Central Slovenia) and have revealed that the mean length and width of the studied hips is the same $(15.90 \pm 0.40 \mathrm{~mm}$ long and 15.90 $\pm 0.40 \mathrm{~mm}$ wide), and mean length and width ratio is $1.01 \pm 0.02$ (the results expressed as mean $\pm \mathrm{SE}$ ). The mean length of hips from Slovenia is the same as the smallest mean length revealed in Lithuania at the site level in Staviškees. The study's authors have indicated that hips are collected from five adjacent plants (Cunsa et al., 2016); therefore, the sampled plants might represent the same clone with small, uniform, almost perfectly globose hips. Interestingly, similar results have been reported from one population in China, where the length and width of hips are nearly the same $(20.40 \pm 0.50 \mathrm{~mm}$ and $20.20 \pm$ $3.60 \mathrm{~mm}$, respectively), and the ratio between the hip width and length is $1.00 \pm 0.15$ (Tong et al., 2017). In other populations from China, studied by ToNG et al. (2017), the ratio between the hip length and width ranges from $0.70 \pm 0.20$ to $0.81 \pm 0.17$ and is like the ratio reported from the populations in Germany, Denmark and Sweden (ZHANG et al., 2018) and similar to that revealed during this study. Therefore, it is quite probable that the almost perfectly globose hips of $R$. rugosa is an inherited character rather than influenced by environmental conditions.

It is usually indicated that the hips of $R$. rugosa have 20-30 mm long erect sepals (CUIZHI \& ROBERTSON, 2003; BRUUn, 2005; LewIS et al., 2014). The results of our study revealed significant variation in the mean sepal length of the studied populations. Sepals were relatively short and quite uniform at some sites, whereas at other sites, they tended to be much longer, and their length was much more variable (Table 2). The values of mean sepal length at two studied sites, Smelte and Pikeliai, were significantly more significant than the reported maximum sepal length (Table 2). During this study, we also noticed that exceptionally long sepals were characteristic of almost all hips of the same shrub, and it enabled us to suppose that this feature may be determined by the genetic properties of the individual.

\section{Variation in different years}

Variation in hip and sepal parameters at the same sites in different years was irregular. In Nemirseta, all values of the hip and sepal parameters were significantly different between the study years. In contrast, at other sites, significant differences were found between one, two or three analysed characters (Table 2, Fig. 3). Such an intricate variation cannot be explained by agrochemical properties of the soil, because differences in all analysed soil features were nonsignificant or even the same in different years. Meteorological conditions also do not explain such variation in years, because the same characters varied irregularly even at closely located coastal sites (Juodkrantè, Avikalnis, Smeltè and Nemirseta) under almost identical meteorological conditions (Table 2, Fig. 3). Analysis of the results on variation in hip and sepal parameters between years according to the site location revealed certain regularities. We found that the mean values of the studied individual parameters at coastal and inland sites also varied irregularly between the study years (Table 2). It should be noted that differences in all studied parameters at inland sites pooled were nonsignificant between the two study years. Differences in hip length were also nonsignificant at coastal pooled sites between the study years. Such a pattern of variation suggests the effects of meteorological conditions. However, revealed re- 
liable correlations did not support this presumption. The variation might be influenced by the microclimatic conditions or other local ecological factors existing at the study sites, particularly in coastal areas, and not analysed during this research (CONTI et al., 2017; OHLER et al., 2020).

Irregular hip and sepal parameter variation in years may also depend on different ageing of fertile shoots of $R$. rugosa. It is possible that the hip and sepal size changes with the increase of absolute age of a shoot (WENK \& FALSTER, 2015; JOHANSSON et al., 2018); however, this phenomenon should be studied separately under experimental conditions. Hip and sepal size may also be influenced by the total hip yield on an individual shrub in a particular year.

\section{Effects of environmental conditions}

The effect of meteorological conditions on the traits of $R$. rugosa, including the characteristics of hips, has been analysed for five sites in China (ToNG et al., 2017). They have found only two reliable correlations between the hip parameters and meteorological conditions: between annual precipitation and hip width, and the length and width ratio. Surprisingly, we found a negative correlation between the sum of annual precipitation and the hip length and width ratio. This relationship contradicts the relationship revealed in China (Tong et al., 2017); however, it is hard to explain the cause of this phenomenon, and further studies based on more sampling sites are required. We also found a strong significant negative correlation between the annual duration of the sunshine and the hip length and width ratio. Moderate negative correlations between the mean annual temperature, mean June temperature and the hip length and width ratio were found. It should be noted that similar results have been obtained in China. Tong et al. (2017) have found a negative, although statistically unreliable, the correlation between mean annual temperature and hip length. We suppose that reaction of $R$. rugosa to meteorological factors may be slow and delayed for a certain period, like in some tree species (KoprowsKi et al., 2012).

Many plant species occur in certain types of soils. The soil chemistry may strongly affect the growth of a plant, its competitiveness and expression of growth, and functional and reproductive traits (FUKAMI \& NAKAJIMA, 2013; Suding et al., 2013). Phosphorus is a key mineral nutrient required for plant growth, fruit set and plant metabolism (HoLFord, 1997; LAMBERS et al., 2011). However, we found a moderate negative correlation between phosphorus content in the soil and sepal length. Thus, $R$. rugosa in the soils with higher phosphorus content produce shorter sepals. A moderate positive correlation between carbonates' content in the soil and sepal length was found in this study. In our opinion, the revealed relationships of sepal parameters with the soil agrochemical properties could be a coincidence or a result of the cumulative effect of the interaction of multiple factors and should be investigated separately.

\section{ACKNOWLEDGEMENTS}

We express our thanks to Ms Vaida Fležinskyte for her assistance during hip sampling in 2008. We also thank Ms Violeta Ptašekienè for the linguistic improvement of the manuscript.

\section{REFERENCES}

Apalia D., ButkienėZ., Reneckiené J., Meljanceva E., Lapinskienè N., Stanionytė A., RylišKienė M., Petrauskaité E., 1978: Raukšletalapis erškètis (Rosa rugosa). - Vilnius.

BruUn H.H., 2005: Biological Flora of the British Isles. Rosa rugosa Thunb. ex Murray. - Journal of Ecology, 93: 441-470. https://doi.org/10.1111/j.1365-2745.2005.01002.x.

BUTKIENE Z., 1971: Biological and biochemical characteristics of rugosa rose. 2. The amount and dynamics of sugar, pectin, tannin and dry soluble matters in fruits. - Lietuvos TSR MA darbai, C serija, 54: 101-109.

Conti L., de Bello F., Lepš J., Acosta A.T.R., CARBOnI M., 2017: Environmental gradients and micro-heterogeneity shape fine-scale plant community assembly on coastal dunes. Journal of Vegetation Science, 28: 762-773. https://doi.org/10.1111/jvs.12533.

Cuizhi G., Robertson K.R., 2003: Rosa Linnaeus. In: Wu Z.Y., Raven P.H., Hong D.Y. (eds), Flora of China. Pittosporaceae through Connaraceae, 9: 296-339. - Beijing-St. Louis.

Cunja V.,Mikulic-PetkovsekM.,WeberN.,JakopičJ., Zupan A., Veberic R., Stampar F., Schmitzer V., 
2016: Fresh from the ornamental garden: hips of selected rose cultivars rich in phytonutrients. - Journal of Food Science, 81: C369-C379. https://doi.org/10.1111/1750-3841.13220.

Dudra A., Strugala P., Pyrkosz-Biardzka K., Sroka Z., Gabrielska J., 2016: A study on biological activity of the polyphenol fraction from fruits of Rosa rugosa Thunb. - Journal of Food Biochemistry, 40: 411-419. https://doi.org/10.1111/jfbc.12228.

European EnVIRONMENT AgENCy, 2017: EUNIS Habitat Classification. - https://www.eea.europa.eu/ data-and-maps/data/eunis-habitat-classification [accessed 5 December 2020].

Fukami T., Nakajima M., 2013: Complex plantsoil interactions enhance plant species diversity by delaying community convergence. - Journal of Ecology, 101: 316-324. https://doi.org/10.1111/1365-2745.12048.

Garbary D.J., Hill N.M., Miller A.G., 2013: Invasion of Rosa rugosa (Rugosa Rose) into coastal plant communities of Brier Island, Nova Scotia. The Canadian Field-Naturalist, 127: 319-331. https://doi.org/10.22621/cfn.v127i4.1513.

GuDŽINSKAS Z., 2000: Conspectus of alien plant species of Lithuania. 16. Rosaceae. - Botanica Lithuanica, 6: 345-364.

GUDŽINSKAS Z., ŽALNERAVIČIUS E., 2017: Invasive plants. - In: BALČIAUSKAS L., ButKus R., Dagys M., GudžInskas Z., Šidagyté E., VaItonis G., Virbickas T., ŽalneravičIUS E., Invasive Species in Lithuania: 27-44. - Vilnius.

Hammer Ø., Harper D.A.T., Ryan P.D., 2001: PAST: Paleontological statistics software package for education and data analysis. - Palaeontologia Electronica, 4: 1-9.

НАsнidoко Y., 1996: The phytochemistry of Rosa rugosa. - Phytochemistry, 43: 535-549. https://doi.org/10.1016/0031-9422(96)00287-7.

Hill N., Beveridge L., Flynn A., Garbary D.J., 2010: Rosa rugosa as an invader of coastal sand dunes of Cape Breton Island and the mainland of Nova Scotia.-TheCanadianField-Naturalist, 124: 151-158. https://doi.org/10.22621/cfn.v124i2.1054.

Holford I.C.R., 1997: Soil phosphorus: its measurements, and its uptake by plants. - Australian Journal of Soil Research, 35: 227-239. https://doi.org/10.1071/S96047.
IsERMANN M., 2003: Rosa rugosa-shrubland in dry coastal dunes. - Verhandlungen der Gesellschaft für Ökologie, 33: 146.

ISERMANN M., 2008: Effects of Rosa rugosa invasion in different coastal dune vegetation types. - In: Tokarska-Guzik B., Brock J.H., Brundu G., Child L., Daehler C.C., Pyšek P. (eds), Plant Invasions. Human Perception, Ecological Impacts and Management: 289-306. - Leiden.

Johansson J., Brännström Å., Metz J.A.J., DieckMANN U., 2018: Twelve fundamental life histories evolving through allocation-dependent fecundity and survival. - Ecology and Evolution, 8(6): 3172-3186. https://doi.org/10.1002/ece3.3730.

Jørgensen R.H., KollmanN J., 2009: Invasion of coastal dunes by the alien shrub Rosa rugosa is associated with roads, tracks and houses. - Flora, 204: 289-297. https://doi.org/10.1016/j.flora.2008.03.002.

KaZlauskiené J., KitrienE Z., 2017: Hidrometeorologijos metraštis, $2016 \mathrm{~m}$. - Vilnius.

Kelager A., Pedersen J.S., Bruun H.H., 2013: Multiple introductions and no loss of genetic diversity: invasion history of Japanese Rose, Rosa rugosa, in Europe. - Biological Invasions, 15: 1125-1141. https://doi.org/10.1007/s10530-012-0356-0.

Kellner A., Ritz C.M., Wissemann V., 2012: Hybridization with invasive Rosa rugosa threatens the genetic integrity of native Rosa mollis. - Botanical Journal of the Linnean Society, 170: 472-484. https://doi.org/10.1111/j.1095-8339.2012.01298.x.

KITRIENĖ Z., 2009: Hidrometeorologijos metraštis, 2008. - Vilnius.

Kollmann J., Jorgensen R.H., Roelsgaard J., Skov-Petersen H., 2009: Establishment and clonal spread of the alien shrub Rosa rugosa in coastal dunes - a method for reconstructing and predicting invasion patterns. - Landscape and Urban Planning, 93: 194-200. https://doi.org/10.1016/j.landurbplan.2009.07.006.

Koprowski M., Przybylak R., Zielski A., PosPiesZYŃSKa A., 2012: Tree rings of Scots pine (Pinus sylvestris L.) as a source of information about past climate in northern Poland. - International Journal of Biometeorology, 56: 1-10.

Kunttu P., Kunttu S.M., 2017: Distribution and habitat preferences of the invasive alien Rosa rugosa (Rosaceae) in Archipelago Sea National 
Park, SW Finland. - Polish Botanical Journal, 62: 99-115. https://doi.org/10.1515/pbj-2017-0009.

Lambers H., Brundrett M.C., Raven J.A., HopPER S.D., 2011: Plant mineral nutrition in ancient landscapes: high plant species diversity on infertile soils is linked to functional diversity for nutritional strategies. - Plant and Soil, 348: 7-27.

Lewis W.H., Ertter B., Bruneau A., 2014: Rosa Linnaeus. - In: Flora of North America Editorial Committee (eds), Flora of North America North of Mexico. Magnoliophyta: Picramniaceae to Rosaceae, 9: 75-119. - New York-Oxford.

MÁrmol I., SÁnchez-De-Diego C., JimÉneZMoreno N., Ancín-Azpilicueta C., RodríguezYoLDI M.J., 2017: Therapeutic applications of rose hips from different Rosa species. - International Journal of Molecular Sciences, 18: 1137. https://doi.org/10.3390/ijms18061137.

Monder M.J., 2012: Evaluation of growth and flowering of cultivars derived from the rugosa (Rosa rugosa Thunb.) growing in the National Collection of Rose Cultivars in the Polish Academy of Sciences Botanical Garden in Powsin. Part I. The historical cultivars. - Acta Agrobotanica, 65: 109-116. https://doi.org/10.5586/aa.2012.064.

Nentwig W., Bacher S., Kumschick S., Pyšek P., VILÀ M., 2018: More than "100 worst" alien species in Europe. - Biological Invasions, 20: 1611-1621. https://doi.org/10.1007/s10530-017-1651-6.

Nordstrom K.F., LAmpe R., VANDEMARK L.M., 2000: Re-establishing naturally functioning dunes on developed coasts. - Environmental Management, 25: 37-51.

Ohler L.M., Lechleitner M., JunKer R.R., 2020: Microclimatic effects on alpine plant communities and flower-visitor interactions. - Scientific Reports, 10: 1366. https://doi.org/10.1038/s41598-020-58388-7.

Olech M., Nowak R., Pecio L., Łoś R., Malm A., Rzymowska J., Oleszek W., 2017: Multidirectional characterisation of chemical composition and health-promoting potential of Rosa rugosa hips. - Natural Product Research, 31: 667-671. https://doi.org/10.1080/14786419.2016.1180601.

Suding K.N., Harpole W.S., Fukami T., Kulmatiski A., MacDougall A.S., Stein C., Putten van der W., 2013: Consequences of plant-soil feedbacks in invasion. - Journal of Ecology, 101: 298-308.

Tong R., Wu X., Jiang L., Si Q., Zang D., 2017: Phenotypic variations in populations of Rosa rugosa. - Acta Ecologica Sinica, 37: 3706-3715. https://doi.org/10.5846/stxb201603230519.

Volungevičius J., Amalevičiūté K., LiaudansKIENĖ I., ŠLepetienė A., ŠLepetys J., 2015: Chemical properties of Pachiterric Histosol as influenced by different land use. Žemdirbystè. Agriculture, 102: 123-132. https://doi.org/10.13080/z-a.2015.102.016

Weidema I., 2006: Invasive Alien Species Fact Sheet. Rosa rugosa. Online Database of the European Network on Invasive Alien Species. - NOBANIS. Available at http:// www.nobanis.org [accessed 20 December 2020].

Wenk E.H., Falster D.S., 2015: Quantifying and understanding reproductive allocation schedules in plants. - Ecology and Evolution, 5(23): 55215538. https://doi.org/10.1002/ece3.1802.

Zhang S., Isermann M., Gan W., Breed M., 2018: Invasive Rosa rugosa populations outperform native populations, but some populations have greater invasive potential than others. - Scientific Reports, 8: 5735. https://doi.org/10.1038/s41598-018-23974-3. 


\section{INVAZINIO RAUKŠLE்TALAPIO ERŠKE்ČIO (ROSA RUGOSA) VAISIŲ IR TAURE்LAPIŲ DYDŽIO VARIACIJA TARP POPULIACIJŲ SKIRTINGAIS METAIS}

\section{Zigmantas GUDŽINSKAS, Mindaugas RASIMAVIČIUS}

\section{Santrauka}

Raukšlètalapis erškètis (Rosa rugosa, Rosaceae) Europoje yra viena labiausiai paplitusių invazinių augalų rūšių. Didžiausią pavojų ji kelia pajūrio buveinių stabilumui ir jų biologinei ịvairovei. Lietuvoje $R$. rugosa yra invazinè rūšis, plačiai paplitusi pajūrio kopose ir žemyninèse pievų, smèlynų bei pamiškių buveinėse. Europoje gana plačiai tyrinètas $R$. rugosa ekologinis poveikis, tačiau duomenų apie augalo reprodukcines savybes ir jų priklausomybę nuo aplinkos sąlygų beveik nèra. Šio tyrimo tikslas - ištirti $R$. rugosa vaisių dydžio ir taurèlapių ilgio variaciją ir šių rodiklių priklausomybę nuo aplinkos sąlygų. Tyrimų medžiaga rinkta 2008 ir 2016 metais. Ištirtos septynios $R$. rugosa populiacijos, esančios pajūrio kopų, žemyninių pievų ir miškų buveinèse. Kiekvienoje populiacijoje buvo surinkta po 100 sunokusių sveikų vaisių. Išmatuotas kiekvieno vaisiaus skersmuo, ilgis ir ilgiausio taurèlapio ilgis. Išnagrinejjus surinktus duomenis buvo nustatyti reikšmingi $R$. rugosa vaisių skersmens, ilgio ir taurèlapių ilgio skirtumai tarp tais pačiais metais tirtų populiacijų. Nustatyta, kad tirtose populiacijose vidutinis vaisių skersmuo $2008 \mathrm{~m}$. $(24,70 \pm 4,98 \mathrm{~mm})$ buvo reikšmingai didesnis negu
$2016 \mathrm{~m} .(23,62 \pm 5.09 \mathrm{~mm})$. Vidutinis vaisiu ilgis $2008 \mathrm{~m} .(17,67 \pm 3,03 \mathrm{~mm})$ ir $2016 \mathrm{~m} .(17,84 \pm$ $3,60 \mathrm{~mm}$ ) reikšmingai nesiskyrè. Vidutinis taurèlapių ilgis tirtose populiacijose $2008 \mathrm{~m}$. buvo reikšmingai didesnis $(29,20 \pm 6,39 \mathrm{~mm})$ negu $2016 \mathrm{~m}$. (26,24 \pm $7,22 \mathrm{~mm}$ ). Nustatytas stiprus neigiamas koreliacinis ryšys tarp saulès švytėjimo trukmès ir vaisiaus ilgio bei skersmens santykio $\left(r_{s}=-0,71, p=0,004\right)$. Vidutinio stiprumo neigiamas ir reikšmingas koreliacinis ryšys nustatytas tarp vaisiaus ilgio ir skersmens santykio bei vidutinès metinès temperatūros $\left(r_{s}=-0,55\right.$, $p=0,040)$. Išnagrinejjus duomenis paaiškèjo, kad tarp fosforo kiekio dirvožemyje ir taurèlapių ilgio yra reikšmingas neigiamas vidutinio stiprumo koreliacinis ryšys $\left(r_{s}=-0,58, p=0,029\right)$, o tarp karbonatų kiekio dirvožemyje ir taurèlapių ilgio yra vidutinio stiprumo teigiamas koreliacinis ryšys $\left(\mathrm{r}_{\mathrm{s}}=0,67\right.$, $p=0,009$ ). Lietuvoje pajūrio buveinèse $R$. rugosa vaisiai buvo didesni negu natūraliame areale Kinijoje. Žemyninèse buveinèse augančių $R$. rugosa vaisių dydis labai nevienodas, bet, norint tiksliau įvertinti jų variacijos priklausomybę nuo buveinių sąlygų, būtini didesnès apimties tyrimai. 